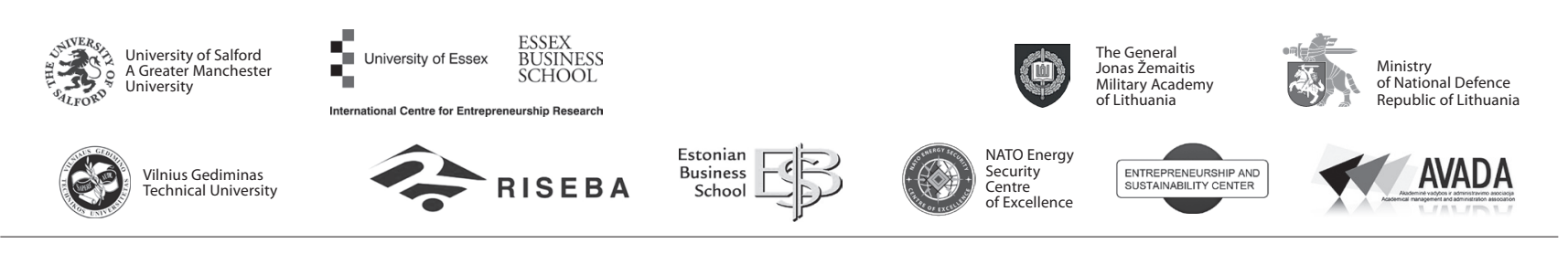

\author{
JOURNAL OF SECURITY AND SUSTAINABILITY ISSUES \\ ISSN 2029-7017 print/ISSN 2029-7025 online \\ 2017 December Volume 7 Number 2 \\ https://doi.org/10.9770/jssi.2017.7.2(10)
}

\title{
SUSTAINABLE BUSINESS MODELING OF CIRCULAR AGRICULTURE PRODUCTION: CASE STUDY OF CIRCULAR BIOECONOMY
}

\author{
Oksana Ryabchenko ${ }^{1}$, Gennadii Golub ${ }^{2}$, Natália Turčeková ${ }^{3}$, Izabela Adamičková ${ }^{4}$, Sergii Zapototskyi ${ }^{5}$ \\ ${ }^{1}$ Slovak university of Agriculture in Nitra/Research Centre AgroBioTech \\ Nelson Mandela University/ Centre of Expertise in Forecasting, Slovak Republic \\ ${ }^{2}$ National University of Life and Environmental Sciences of Ukraine, \\ Department of the Machines and Bioenergy systems, Ukraine \\ ${ }^{3,4}$ Slovak university of Agriculture in Nitra/Faculty of Economics and Management, Nitra, Slovak Republic \\ ${ }^{5}$ Taras Shevchenko National University of Kyiv, Faculty of geography, Ukraine \\ E-mails:'oksana@nubip.edu.ua; '2gagolub@ukr.net; ${ }^{3}$ nturcek@gmail.com; \\ 4izabela.adamickova@uniag.sk; 5zapototsk@knu.ua
}

Received 26 March 2017; accepted 12 November 2017

\begin{abstract}
The current agricultural production is facing different challenges. Successful solutions require improvement of production system based on sustainability. As such it is able to provide both economic and environmental performance based on products diversifications, energy efficiency and closing loop in agriculture. To solve this, imitation models of circular agriculture production system created by linear modeling was proposed in the study. Modeling was done base on the real data of one of the Ukrainian agriculture production region. The region with the middle continental environmental condition was taken as a base. This is making proposed example suitable to apply in the other European countries with similar conditions.
\end{abstract}

Key words: sustainability, agriculture production circular system, soil organic matter balance, agriculture waste valorization, bioenergy production.

Reference to this paper should be made as follows: Ryabchenko, O.; Golub, G.; Turčeková, N.; Adamičková, I., Zapototskyi, S. 2017. Sustainable business modeling of circular agriculture production: case study of circular bioeconomy, Journal of Security and Sustainability Issues 7(2): 301-309. https://doi.org/10.9770/jssi.2017.7.2(10)

JEL codes: Q1

\section{Introduction}

There are few current challenges of agricultural production development:

- Traditionally agriculture is the main source of food supply. Simultaneously, it is one from three sources of biomass generation for bioenergy and biopolymers purpose. Sectors what generate commodities with higher value-add chain. This leads to increased competition for raw materials between sectors and food security risks.

- Agriculture is a highly subsidized industry in many countries. This fact generates an economic instability for the producer through dependence on subsidies and limits their production potential.

- Natural conditions are the main production assets of agriculture production. In the other words, farmers strongly depend on the climate and natural conditions (access to water, soil quality and etc.) Thus, agriculture is most in need of adaptation and mitigation to existing climate change. 
- From other hand, agriculture is one of the main sources of environmental pollution, water using and soil degradation.

In this case, the comprehensive solution requires overcoming the contradiction between increasing of environmental load and keeping the balance of food and feed supply with the existing level of population growth. The main task of current agriculture studies lies around to find the most effective decisions in terms of sustainable development of the system which targets to the food supply, energy security, economy and social development.

The development of sustainable business models for agricultural production circular system (APCS) is one of the approaches that allow overcoming the indicated challenges. There are numerous of studies focused on the finding optimal agriculture production business models (Balitskiy et al. 2014; Stępień and Miciuła 2016; Czyżewski and Smędzik-Ambroży, 2015). Some of them orientated on the soil nutrient balance optimization through the complex solution in agriculture, such as Banasik et al. (2017), innovative findings (Azimova et al. 2017) other one target to achieve social balance through the diversification of agriculture production (Sengera et al. 2017; Reiff et al., 2016) and a lot of attention direct to the implementation of bioenergy production into the agriculture system as a key factor of environmental stabilization and increasing of energy efficiency (Strielkowski, Lisin, 2012; Karlsson et al. 2016; Chodkowska-Miszczuk and Zymańska 2013; Kharlamova, 2016; Simionescu et al., 2017). Actually, the finding of technologically flexible and socially oriented agroecosystem is the main idea all many studies (Tvaronavičienė et al., 2015; Zemlickiene et al., 2017; Dobrovolskienė et al., 2017; Tvaronavičienè 2017; Tvaronavičienè, Razminienè, 2017).

However, we suggested reaching models for agriculture production circular system based on the real data such as existent agriculture and bioenergy production technologies and natural conditions. Here, APCS is highly technological agriculture system with the same orientated to the economic and environmental performance. Definition was adopted for this paper based on the study done by Vandermeer (2011).

The main objective of this study is the creation of an economically efficient and environmentally sustainable model of agricultural production system based on products diversification, bioenergy use and closed loop material flows in agriculture supply chain.

Reaching this target, the imitation model based on the linear modeling was proposed. APCS models include five main productions modules: crop production (CP), livestock farming (contains cattle breeding and poultry) (LF), bioenergy production (BE), fish farming (FF) and mushroom production (MP). Crop production based on the crop rotation typical for agro ecosystem involves food and feed crops. Cattle breeding shared between dairy farm and pig production. The energy base is the production of heat and electricity from biogas obtained from fermentation of manure, litter, and other liquid organic wastes. Biogas feedstock is limited by the accessible "non-grain" part of the crop in the form of rolls, bales, ribs or granules, briquettes, and generator gas, based on straw. The raw material base for the production of liquid fuels is also an integral part of proposed APCS model. Mushroom production provides chain to keeping soil nutrient balance. Diversification of agricultural production creates crucial economical prerequisite for maintaining crop fertility on the basis of compost production using the biological conversion of organic raw materials.

For modeling of such comprehensive system, it is required to use an integrated and well-balanced approach to connect all modules efficiency. The approved methods and existing technologies are used as a base. Their description is in the "Approach" part of this study. Comparative economic efficiency was done for the systems with a different combination of production modules and the result was spelled out in the part of "Research results". Conclusion and discussion were proposed. 


\section{Approaches}

APCS models include five main productions modules: crop production (CP), livestock farming (cattle breeding and poultry included) (LF), bioenergy production (BE), fish farming (FF) and mushroom production (MP). Total harvested area is 300 hectares. Crop rotation is orientated to food, feed and energy potential crops such as winter wheat, winter rapeseed, sugar beet, corn, green maize, barley and grass (Table 1).

Table 1. Crop rotation scheme

\begin{tabular}{c|c} 
Agriculture crops & Harvested area, ha \\
\hline Winter wheat & 50 \\
Winter rapeseed & 50 \\
Sugar beet & 50 \\
Corn & 25 \\
Green Maize & 25 \\
Barley & 50 \\
Grass & 50 \\
\hline
\end{tabular}

Source: Set of technical production specification (UCAB, 2016.)

Each from five blocks deals with materials flows such as input, outcomes and interim output. Input data for $\mathrm{CP}$ and LF modules were obtained from existing product specification of Ukrainian farms (Ukrainian Club of AgroBisness, 2016). It is important to note, that the model was developed in correspondence with existing and most common technologies for each production module. Hence, input data can be changed due to natural conditions, apply technologies, quality of seeds and etc.

Outcomes are the end results of production per each module what can be represented as commodities out of production system (Table 2). There are provided as outcomes grains, pork, beef, fish, milk, eggs, oils, sugar, honey, and mushrooms. In addition, the proposed APCS model involves the biofuel production in the amount covering current production's needs as well as biogas for further obtaining electricity and heat. Solid fuels getting from the crop residues can be used for the heating purpose.

Table 2. Outcomes and interim outputs material flows per production module.

\begin{tabular}{|c|c|c|c|c|c|c|c|c|c|}
\hline \multicolumn{2}{|c|}{$\mathrm{CP}$} & \multicolumn{2}{|c|}{ LP } & \multicolumn{2}{|c|}{$\mathrm{BE}$} & \multicolumn{2}{|c|}{$\mathrm{FF}$} & \multicolumn{2}{|c|}{ MP } \\
\hline Outcomes & $\begin{array}{l}\text { Interim } \\
\text { Output }\end{array}$ & Outcomes & $\begin{array}{l}\text { Interim } \\
\text { Output }\end{array}$ & Outcomes & $\begin{array}{l}\text { Interim } \\
\text { Output }\end{array}$ & Outcomes & $\begin{array}{l}\text { Interim } \\
\text { Output }\end{array}$ & Outcomes & $\begin{array}{l}\text { Interim } \\
\text { Output }\end{array}$ \\
\hline Corn grain & Feed & Beef & $\begin{array}{c}\text { Solid } \\
\text { manure }\end{array}$ & Biodiesel & Precipitate & Fish fillet & $\begin{array}{l}\text { Waste } \\
\text { water }\end{array}$ & Champignon & $\begin{array}{c}\text { Used } \\
\text { substrate }\end{array}$ \\
\hline Barley grain & $\begin{array}{l}\text { Other crop } \\
\text { residues }\end{array}$ & Milk & $\begin{array}{l}\text { Liquid } \\
\text { manure }\end{array}$ & Bioethanol & $\begin{array}{l}\text { Glycerin } \\
\text { sediment }\end{array}$ & & & $\begin{array}{c}\text { Oyster } \\
\text { mushroom }\end{array}$ & \\
\hline Wheat grain & Straw & Pork & & Electricity & & & & & \\
\hline Sugar & & Eggs & & Heat & & & & & \\
\hline Honey & & & & & & & & & \\
\hline
\end{tabular}

Source: based on the own processing

The interim output is defined as material flows got as a production result from one module and used as the input for the next production stage or reaching natural soil balance (Figure 1). The fodder value of crop were determined according to existing methods for diary (Miller-Cushon and De Vries, 2017), pig breeding (Li and Jonh, 2016) and polutry production (Gangadoo and all, 2016). Measuring of crop residues output as well as the rates of yield and moisture of the bird droppings are based on the methods proposed by Makartsev. The size of chicken population was determined on the basis of the available feed base and its feed needs (Makartsev, 2012). On the basis of the available amount of organical matters and its nutrient content a compost mixture was 
developed and the content of total nitrogen was $2 \%$, phosphorus- 1 , potassium- 1,5 and calcium- $2,5 \%$ in the dry matter (Pandey and all, 2017). The content of organic nitrogen in the soil is about $5 \%$. This means consumed $50-60 \%$ of nitrogen from soil over one harvesting period. Organic nitrogen is obtained as the result of soil's fermentation processes. The transformation process of natural originate feedstock to organic soil matter would call bioconversion, in this study.

Mushroom production is able to provide bioconversion in conditions close to the optimal for each type of microflora, creating an agricultural production close loop circle as well as to obtain additional protein production (Banasik and all, 2017). The used substrate after the cultivation of mushrooms is high-quality organic fertilizer. A mixture of substrate with a covering soil contains from 1.3 to $1.8 \%$ of dry nitrogen and 20 to $40 \%$ of other organic matter, as well as a number of macro- and micronutrients (Devochkin, 1989). The main parameters of substrate production were calculated based on the work done by Devotchkin. The assessment of soil organic matter (SOM) balance for the proposed crop rotation was calculated using approaches proposed by FAO (Roy and all, 2007) based on the agrochemical balances. Winter wheat yield was used as a basis crop for SOM balance modeling (Figure 1).

Calculation based on the measuring of minimal level of wheat yield is necessary to reach optimal economic and environmental performance.

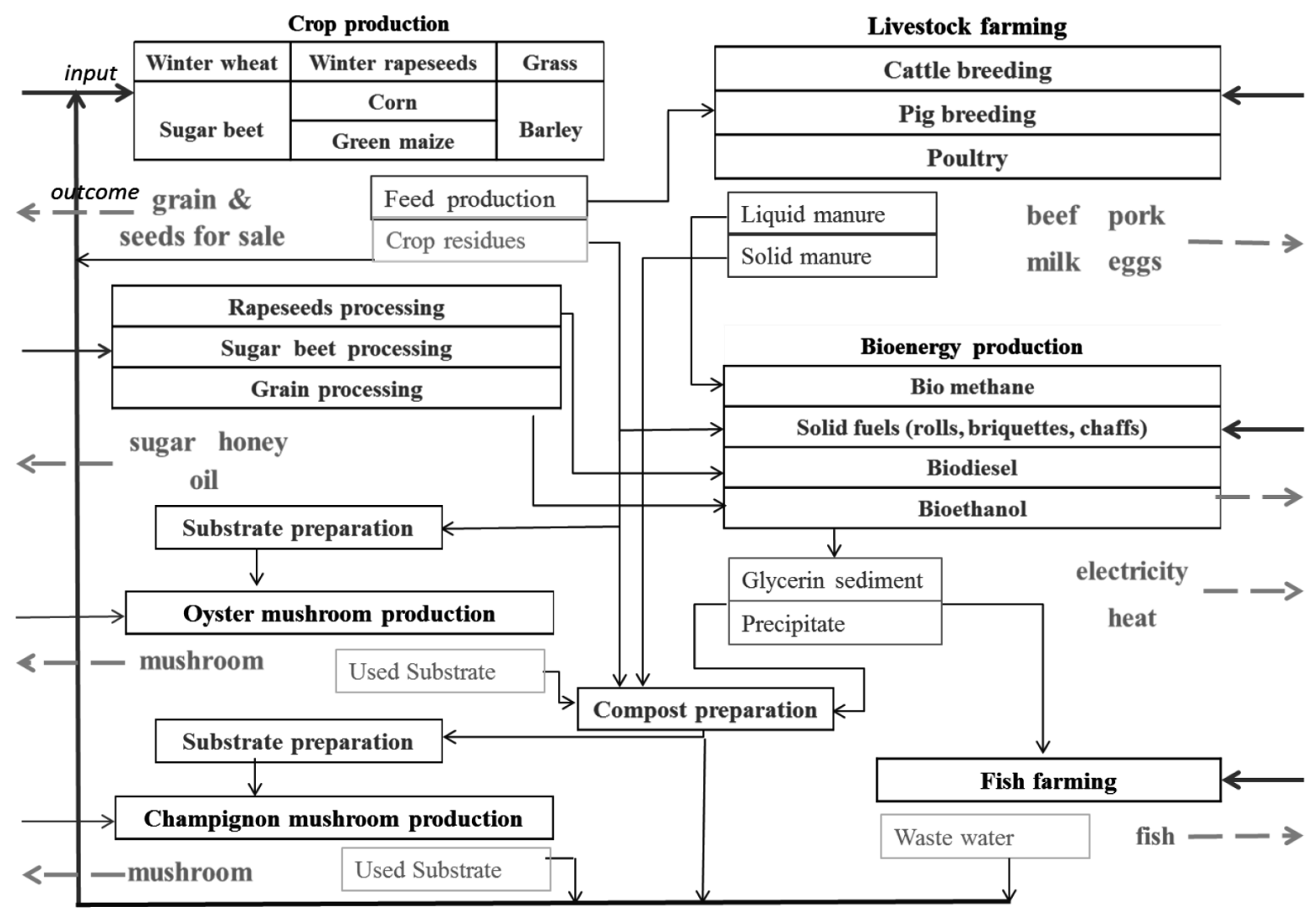

Figure 1. Outcomes and interim output materials flows for APCS model.

Source: based on the own processing

Current production needs of biofuels were obtained from excitant technical product specification. They are about 4.8 tons of bioethanol and 23.1 tons biodiesel. Their production requires 14 tons of wheat grain and 125 tons of rapeseed. Adopting the assumption that the volume of produced biogas is determined by the intensity of organic matter decomposing during organic biomass fermentation, biogas yield was obtained as follows (while fermentation in terms of normal conditions): 


$$
V=P\left(1-\frac{W}{100}\right) c c_{i} \frac{v}{\rho},
$$

where:

$V$ is a specific biogas yield from the reactor under normal conditions, $m^{3}$ per day;

$P$ - biomass density, $\mathrm{kg} / \mathrm{m}^{3}$;

$W$ - biomass dampness, $\%$

$\left(1-\frac{W}{100}\right)-$ dry matter content correspond to the total biomass, $\mathrm{kg}$

$\mathrm{c}$ - organic matter content regarding to the total volume of dry fermenting biomass, $\mathrm{kg}$

$c_{i}$ - the number of decomposed organic matter regard the total volume of organic matter per day;

$v$ - biogas yield per unit of decomposed organic matter, $\mathrm{kg}$;

$p$ - biogas density under normal conditions, $\mathrm{kg} / \mathrm{m}^{3}$.

To make the clear results of closing loop performance of the proposed model, comparative analysis of production systems excluding BE and LP modules was proposed.

\section{Research results}

Agricultural production circulatory system model targeting the economic and environmental efficiency based on the closed-loop material flow was proposed in this study. Economic and environmental performance of outcomes and interim output were analyses based on the minimal level of yield for basis crop. Economic and environmental performance of production outcomes and interim outputs were analyzed based on the minimal level of yield for basis crop. The yield of winter wheat was accepted as a basis due to the fact, that it is a core source of food and feeds supply, bioenergy production, and soil matter recovering.

The economic effectiveness of outcomes from five working modules was calculated based on the yield basis crop (Table 3). To note, at this work, model calculated from the lowest level of yields to the to " yield breakeven point" correspond to the environmental and energy efficiency. It allows optimizing economic and environmental performance of the system (Table 3 ).

Table 3. Economic efficiency of the APCS to the basis crop yield (excluding BP module)

\begin{tabular}{ccccc}
\hline Outcomes, & \multicolumn{5}{c}{ Wheat yield, t/ha } \\
CP, LF, FF, MP & 2.0 & 2.5 & 3.0 & 3.5 \\
\hline Wheat grain, t & 86 & 111 & 136 & 161 \\
Oil, t & 0 & 4.3 & 10 & 15.7 \\
Sugar, t & 84 & 105 & 125 & 146 \\
Honey, t & 5 & 5 & 5 & 5 \\
Pork, t & 13.0 & 16.2 & 19.5 & 22.7 \\
Beef, t & 12.7 & 14.7 & 17.6 & 20.5 \\
Milk, t & 318 & 397 & 476 & 556 \\
Eggs, ths & 100 & 200 & 300 & 400 \\
Fish, t & 9.6 & 11.9 & 14.3 & 16.7 \\
Mushroom, t & 20 & 23 & 27 & 30 \\
\hline
\end{tabular}

Source: own calculation 
Obviously, maximisation of basis crop yield leads to the economic efficiency maximisation of the systems with $\mathrm{CP}$ and LF modules. However, the profitability level of the system including BP module could be increased upper more than $51 \%$. This is due to the use of own produced heat and electricity from biomass (Table 4).

Table 4. Economic efficiency of the APCS to the basis crop yield (including BP module)

\begin{tabular}{|c|c|c|c|c|}
\hline \multirow{2}{*}{ Outcomes } & \multicolumn{4}{|c|}{ Wheat yield, $t / h a$} \\
\hline & 2.0 & 2.5 & 3.0 & 3.5 \\
\hline \multicolumn{5}{|l|}{ Heat } \\
\hline Production capacity, GJ & 1475 & 2063 & 2650 & 3238 \\
\hline Consumption, GJ & 1360 & 1400 & 1440 & 1480 \\
\hline Covering, $\%$ & 109 & 147 & 184 & 219 \\
\hline \multicolumn{5}{|c|}{ Electricity } \\
\hline Production capacity, ths. kWh & 44 & 54 & 65 & 75 \\
\hline Production capacity including heat excess, ths. kWh & 83 & 248 & 413 & 578 \\
\hline Consumption, ths. kWh & 1600 & 1988 & 2386 & 2783 \\
\hline Covering, $\%$ & 5 & 12 & 17 & 21 \\
\hline Biodiesel, t & 21.7 & 23.1 & 23.1 & 23.1 \\
\hline Bioethanol, t & 4.8 & 4.8 & 4.8 & 4.8 \\
\hline
\end{tabular}

Source: own calculation

The culculation results show, that APCS is able to meet own needs for heat at a wheat yield upper of $2 \mathrm{t}$ per ha (Figure 2). At a higher yield of cereal, excess heat energy should be converted into electrical energy, while increasing the level of electricity supply. Biofuels production volumes are defined by current needs but also can be regulated due to economic efficiency. Producers are able to make a decision about wheat and rapeseed utilization according to current energy and agriculture market prices.

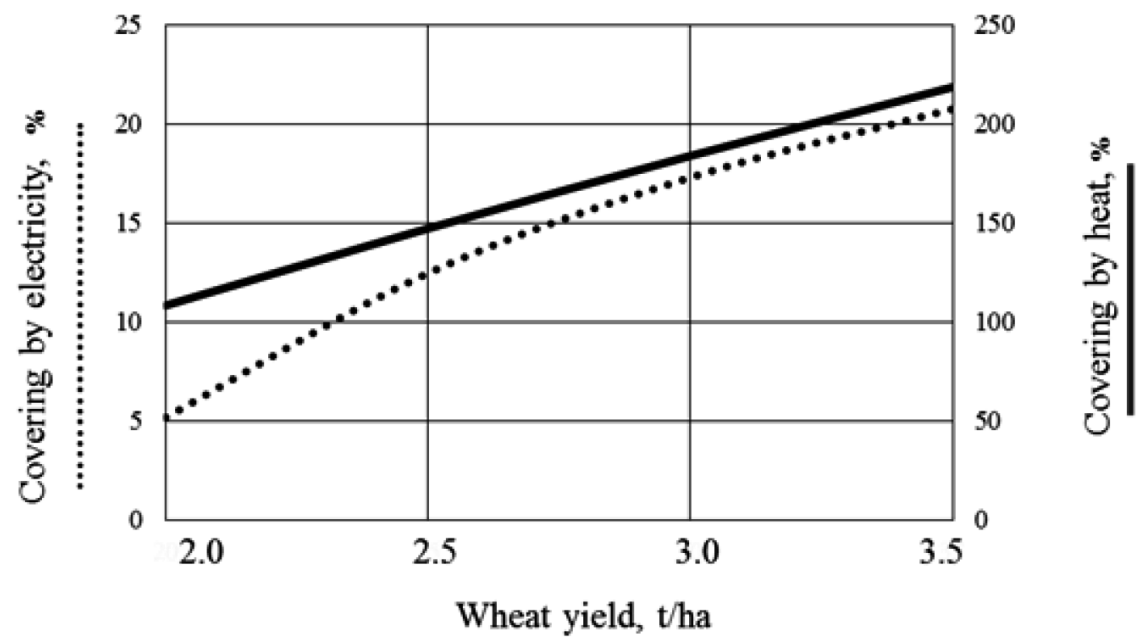

Figure 2. Energy supply ratio covering own production

Source: based on the own processing

Profitability of mushroom production can be within $10-18 \%$ in the overall structure of economic efficiency (depends on the market prices). Thus, it allows compensating compost production costs. Compost is a key component in achieving environmental sustainability through the SOM recovery. Utilization of 78 tons of straw allows producing 1764 tons of compost. It requires $8 \%$ of total compost volume with the production of oyster mushroom ( 7 tons) and champignon mushrooms (20 tons) (Table 3). The rest $92 \%$ can be used to reaching soil organic matter balance $\geq 0$ under the condition of wheat yield 3 t per hectare and higher. 
Table 5. Environmental efficiency of the APCS to the basis crop yield

\begin{tabular}{ccccc}
\hline Environmental & \multicolumn{4}{c}{ Wheat yield, $\mathrm{t} / \mathrm{ha}$} \\
Outcomes & 2.0 & 2.5 & 3.0 & 3.5 \\
Compost, t & 1197 & 1481 & 1764 & 2048 \\
SOM & -305 & -152 & 0 & 152 \\
\hline
\end{tabular}

Source: own calculation

However, comparative analyses provided results with the most efficient SOM balance match to the production system without BP module. In this case positive SOM balance can be achieved with wheat yield upper than $2.2 \mathrm{t}$ per hectare (Figure 3).

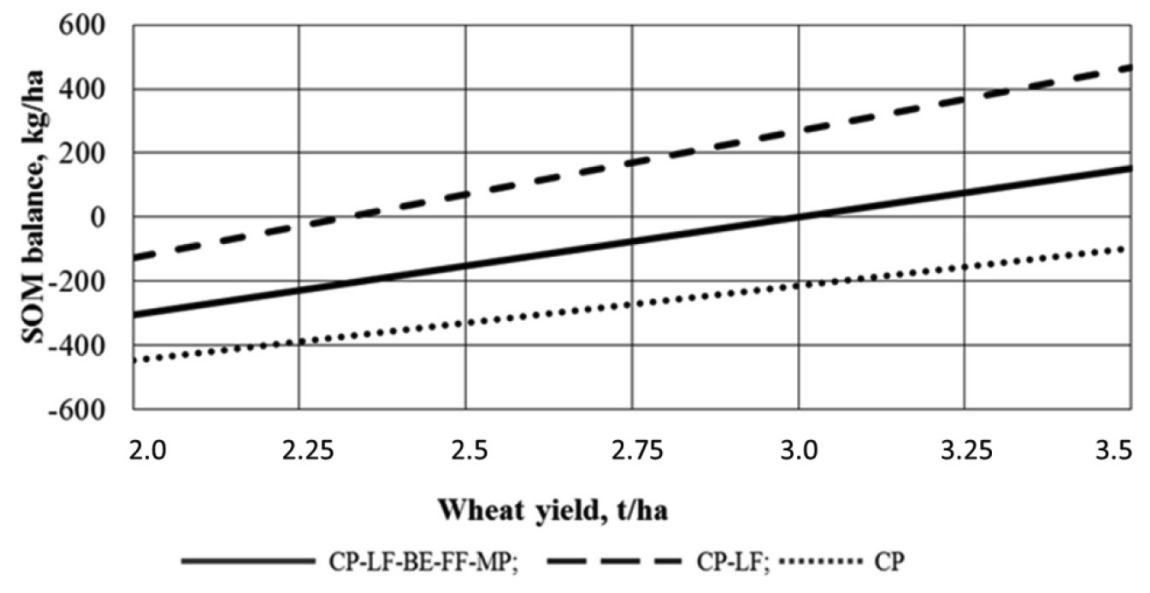

Figure 2. SOM balance under the different production systems

Source: based on the own processing

Besides, it is impossible to achieve the positive SOM balance under the production system focused only on the crop production.

\section{Conclusions}

Proposed APCS model provides the approach of agricultural production decision optimization towards sustainability.

Five productions modules based on the biotechnologies are able to maximize the economic efficiency of available biomass using waste utilization. At the same time, the bioconversion based on the mushroom production intensifies the process of soil matter recovery using waste from plants and animals.

However, mushrooms and substrate production capacity strongly correlate to the available crop residue. Therefore in each particular case, it is necessary to calculate their limiting production intensity regards to the accessible raw materials. Failure to comply with this requirement leads to SOM negative balance and a decrease in soil fertility.

Each element of the proposed production module can be adapted depending on the actual technical conditions, production capacity and market characteristics. 
We recognize here, proposed APCS model is the most suitable for implementation in the regions matching the Type $3^{1}$ and $4^{2}$ within the EU classification according to the extent bioeconomy profile. It's also possible to adopt it for the regions matching classification under Type $5^{3}$ (EC, 2017).

\section{Acknowledgement}

This work was supported by AgroBioTech Research Centre built in accordance with the project Building "AgroBioTech” Research Centre ITMS 26220220180.

\section{References}

Azimova, S. T.; Kizatova, M. Z.; Akhmetova, O. S.; Donchenko, L. V.; Admayeva, A. M. 2017. Towards food security through application of novel scientific findings, Journal of Security and Sustainability Issues 6(4); 719-728. https://doi.org/10.9770/jssi.2017.6.4(16)

Balitskiy, S.; Bilan, Y.; Strielkowski, W. 2014. Energy security and economic growth in the European Union, Journal of Security and Sustainability Issues 4(2):123-130. http://dx.doi.org/10.9770/jssi.2014.4.2(2)

Banasik, A.; Kanellopoulo, A.; Claasse, G.D..; Bloemhof-Ruwaard, J.M.; Van der Vorst, J.G. 2017. Closing loops in agricultural supply chains using multi-objective optimization: A case study of an industrial mushroom supply chain. International Journal of Production Economics 183: 409-420

Banasik, A.; Kanellopoulos, A.; Jacqueline, G.D.; Bloemhof-Ruwaard, M.; Van der Vorst, J.G. 2017. Closing loops in agricultural supply chains using multi-objective optimization: A case study of an industrial mushroom supply chain. International Journal of Production Economics 183(Part B): 409-420

Chodkowska-Miszczuk, J.; Szymańska, D. 2016. Agricultural biogas plants-A chance for diversification of agriculture in Poland. Renewable and Sustainable Energy Reviews 20: 514-518

Czyżewski, A.; Smędzik-Ambroży, K. 2015. Specialization and diversification of agricultural production in the light of sustainable development, Journal of International Studies 8(2): 63-73. http://dx.doi.org/10.14254/2071-8330.2015/8-2/6

Devochkin L.A. 1989. Champignon. Moskva. Agropromisdat. 1989. p. 175 ISBN 5-10-000598-X

Dobrovolskienè, N.; Tvaronavičienè, M.; Tamošiūnienè, R. 2017. Tackling projects on sustainability: a Lithuanian case study, Entrepreneurship and Sustainability Issues 4(4): 477-488. http://dx.doi.org/10.9770/jesi.2017.4.4(6)

EC, Bioeconomy Development in EU regions. 2017 Writen by Haarch S. Available on-line: https://ec.europa.eu/research/bioeconomy/ pdf/publications/bioeconomy_development_in_eu_regions.pdf

Gangadoo, S.; Stanley, D.; Hughes, R.J.; Moore, R.J.; Chapman, J. 2016. Nanoparticles in feed: Progress and prospects in poultry research. Trends in Food Science \& Technology 58: 115-126

Karlsson, N. P.E.; Halila, F.; Mattsson, M.; Hoveskog, M. 2017. Success factors for agricultural biogas production in Sweden: A case study of business model innovation Journal of Cleaner Production 142: 2925-29

Kharlamova, G.; Nate, S.; Chernyak, O. 2016. Renewable energy and security for Ukraine: challenge or smart way?, Journal of International Studies 9(1): 88-115. http://dx.doi.org/10.14254/2071-8330.2016/9-1/7

Li, Q.; Jonh, F. 2016. Factors involved in the regulation of feed and energy intake of pigs. Animal Feed Science and Technology, Available online: http://www.sciencedirect.com/science/article/pii/S0377840116300013

Makartsev, N.G. 2012. Livestock feeding. Text book. Therd edition. Caluga, Noosphera. 120-152. p. 641 ISBN 978-5-905856-01-3. https://fermer.ru/files/v2/forum/225013/10255682.pdf

Miller-Cushon, E.K.; De Vries, T.J. 2017. Feed sorting in dairy cattle: Causes, consequences, and management. Journal of Dairy Science 100(5): 4172-4183

1 Type 3: Regions with a primary value chain bioeconomy profile (incipient)

2 Type 4: Region with a primary value chain bioeconomy profile (advanced)

3 Type 5. Regions with industrial biotech profile 
Pandey, A.; Larroche, C.; Current Advances in Solid-State Fermentation. Current Developments in Biotechnology and Bioengineering.

Pandey A. (Ed.) Textbook. p 258-314. Available on-line. http://www.sciencedirect.com/science/article/pii/B9780444639905000141

Reiff, M.; Surmanová, K.; Balcerzak, A.P.; Pietrzak, M.B. 2016. Multiple Criteria Analysis of European Union Agriculture, Journal of International Studies 9(3): 62-74. https://doi.org/10.14254/2071-8330.2016/9-3/5

Roy, R.N.; Misra, R.V.; Lesschen, J.P.; Smaling, E.M. 2007, Assessment of Soil Nutrient Balance: Approaches and Methodologies. FAO. Rome.2007.ISBN 978-92-5-105038-5. Available on-line http://www.fao.org/docrep/006/y5066e/y5066e08.htm

Sengera, I.; Rossi, J.A.; Dessimon Machadoc, B.J. 2017. Using the theory of planned behavior to understand the intention of small farmers in diversifying their agricultural production. Journal of Rural Studies 49:32-40

Simionescu, M.; Albu L. L.; Szeles M. R, \& Bilan, Y. 2017. The Impact of Biofuels Utilisation in Transport on the Sustainable Development in the European Union. Technological and Economic Development of Economy 23(4): 667-686. https://doi.org/10.3846/202949 13.2017.1323318

Stępień, P.; Miciuła, I. 2016. Liberalization of the Polish energy market and the EU commitments. Czech Journal of Social Sciences, Business and Economics 5(2):25-33. http://dx.doi.org/10.24984/cjssbe.2016.5.2.3

Strielkowski, W.; Lisin, E. 2012. It's the end of the world (as we know it): an economist's perspective. International Economics Letters 1(1):1-9. http://dx.doi.org/10.24984/iel.2012.1.1.1

Tvaronavičienė M., Razminienė K. 2017. Towards competitive regional development through clusters: approaches to their performance evaluation, Journal of Competitiveness 9(4):. 133 - 147 http://dx.doi.org/10.7441/joc.2017.04.09

Tvaronavičienè, M. 2017. Clusters, innovations and energy efficiency: if relationship could be traced, Marketing and Management of Innovations 2: 382 - $391 \mathrm{http}: / / \mathrm{dx}$. doi.org/10.21272/mmi.2017.2-35

Tvaronavičienė, M.; Mačiulis, A.; Lankauskienė, T.; Raudeliūnienė, J.; Dzemyda, I. 2015.Energy security and sustainable competitiveness of industry development, Economic research = Ekonomska istraživanja. 28(1): 502-516. http://dx.doi.org/10.1080/133167 7 X.2015.1082435

Ukrainian Club of Agribusiness. 2016. Set of technical production specification. UCAB. p 92 Available on the internet www.ucab.ua Vandermeer J. 2011. The inevitability of surprise in agroecosystems. Ecological Complexity 8(4): 377-382

Zemlickiene, V.; Mačiulis, A.; Tvaronavičienè, M. 2017. Factors impacting the commercial potential of technologies: expert approach, Technological and Economic Development of Economy 23(2): 410-427 http://dx.doi.org/10.3846/20294913.2016.1271061 